\title{
IMPLEMENTATION OF MUROTTAL AL-FATIHAH AGAINST CLIENTS RISK OF VIOLENCE AT THE CLENDER HOSPITAL, EAST JAKARTA
}

\author{
Amrullah, Asih Minarningtyas, Hani Fauziah
}

Nursing Study Program, STIKES Bani Saleh , Bekasi, Indonesia

\begin{abstract}
Data from the World Health Organization (WHO) (2009) estimates that 450 million people worldwide experience mental disorders, about $10 \%$ of adults experience mental disorders and $25 \%$ of the population is estimated to experience mental disorders at a certain age during their life. This age usually occurs in young adults between the ages of 18-21 years. Other data from the National Institute of Mental Health shows that the rate of mental disorders reaches $13 \%$ of the disease as a whole and is expected to grow to $25 \%$ in 2030. The highest prevalence of mental disorders in Indonesia is in the province of the Special Capital Region (DKI) Jakarta (24, 3\%), followed by Nagroe Aceh Darussalam (18.5\%), West Sumatra (17.7\%), NTB (10.9\%), South Sumatra (9.2\%), and Central Java (6.8\%). while based on data Basic Health Research (2007). It shows that the national prevalence of mental disorders reaches $5.6 \%$ of the population, four to five people are suffering from mental illnesses. Based on these data, Indonesia's annual data that experience mental disorders is always increasing $(\mathrm{MOH}$ (2008). The increase in the proportion of mental disorders in the data obtained in Riskesdas 2018 is quite significant compared to Riskesdas in 2013, increasing from $1.7 \%$ to $7 \%$ of Indonesia's population (Riskesdas, 2018). In our country, there are approximately 2,400,000 children with mental disorders.
\end{abstract}

\section{Keywords: Murottal Alfateha. Violent Behavior}




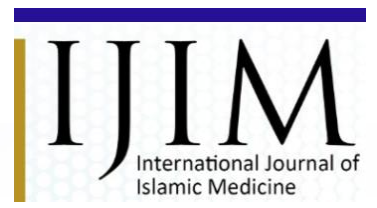

\section{INTRODUCTION}

The cultural development of society has brought about many changes in the aspects of human life. Every change in individual life conditions, either positive or negative, can affect physical, mental and, social balance. A person's health status is in line with technological developments. More problems must be faced and overcome by a person challenging to achieve life welfare. This situation has a huge impact on one's mental health, which means that the people with mental disorders will potentially increase.

Mental disorders are syndromes or patterns of clinically meaningful behavior that are related to distress or suffering and cause impairment in one or more functions of human life. Mental disorders are classified in the form of diagnosis classification. In Indonesia, the classification of a diagnosis of mental disorders is called the Guidelines for Diagnosis of Mental Disorders (PPDGJ)which management of mental disorders, 2009)

Data from the World Health Organization ( WHO) (2009) estimates that 450 million people worldwide experience mental disorders, about $10 \%$ of adults experience mental disorders, and $25 \%$ of the population is estimated to experience mental disorders at a certain age during their life. This age usually occurs in young adults between the ages of 18-21 years. Other data from the National Institute of Mental Health shows that the rate of mental disorders reaches $13 \%$ of widespread diseases and is estimated to grow to $25 \%$ by 2030 . The highest prevalence of mental disorders in Indonesia are in the province of Special Capital Region (DKI) Jakarta (24.3\%), followed by Nanggroe Aceh Darussalam (18.5\%), West Sumatera (17.7\%), NTB (10.9\%), South Sumatra (9.2\%), and Central Java (6.8\%). while based on data from Basic Health Research (2007)

It shows that the national prevalence of mental disorders reaches $5.6 \%$ of the population, four to five people are suffering from mental disorders. Based on these data, the data per year in Indonesia experiencing mental disorders increases (MOHRI (2008). The increase in the proportion of mental disorders in the data obtained in Riskesdas 2018 is quite significant when compared to Riskesdas in 2013, increasing from $1.7 \%$ to $7 \%$ of the population. Indonesia (Placeholder2) (Riskesdas, 2018).

In our country, there are approximately 2,400,000 children with mental disorders (Maramis, 2004) in Minarningtyas et al. 2015) (Asih MinarningTyas, 2015)The term used in the Al Quran to describe the soul is nafs, giving the meaning of the soul (nafs) as a spirit that is one with the body which functions to encourage people to behave. In the letter Ash Shams (91: 7-11), the Word of God states that: And the soul and its perfection (creation). So Allah inspires the soul (the way) of its wickedness and righteousness. Indeed it is fortunate that the person who purifies the soul. And actually, be guilty of those who dirty it. These verses explain that Allah created the soul, then allowed him to choose the path of wickedness or righteousness. The human soul contains both badness (denial) and goodness (holiness). The soul encourages humans to do good or evil so that people who 
purify their souls become lucky people, that is, they tend to do good, and humans who pollute their souls become losers, namely tend to evil (evil). (Uyun, 2014) .

The risk of violent behavior is the behavior of a person who shows that they can endanger themselves or others or the environment, both physically, emotionally, sexually, and verbally. The risk of violent behavior is divided into two: the risk of violent conduct against oneself ( risk for self-directed violence) and the risk of violent behavior against others (risk for other-directed violence). NANDA (2016) in (Sutejo, 2017)

Spiritual remedies can prevent violent behavior. One of them is Murottal therapy. Ibnu Qayyim states in his book Zaadul Ma'aad, juz 3, pp. 178-179, as quoted by Moh Sakhowi El Quds and Moh Syamsi Hasan: Al-Qur'an is physical medicine, emotional, sexual, and verbal is perfect (useful) for all diseases of the heart and body, the world and the hereafter. However, not everyone is gifted with the expertise and ability to perform healing with the Qur'an. If the treatment through the Qur'an is carried out correctly, correctly, full of faith and faith and a solid heart, and meets the requirements, then there is no. one disease can fight it. How can there be a disease that is able to fight and defeat the words of Allah, the Creator of the heavens and the earth, if the word were to be lowered on a mountain, of course, it would be flexible, bow and bow solemnly 'or on the planet, of course, it would be broken into pieces. . So there is no disease, either liver disease or bodily disease, but of time in the Qur'an, there are solutions that indicate the cure, and the causes and reasons thereof for those who have been granted by Allah the understanding to understand His holy book. Whoever is not healed by the Qur'an, Allah will not provide healing for him. And whoever is not sufficient with the Qur'an, it means that Allah does not provide sufficiently for him. Amelia, (2006) in Khotimah 2018).

The Qur'an is the perfect healer for all ailments of the heart and body. Diseases of the world and the hereafter. Treatment with the Qur'an should base on good intentions, sure of healing from it. Allah Subhanhu wata'ala says, which means " And We send down from the Koran that a bidder and a mercy to those who believe the Koran and it u not add to the people who do wrong other than loss" (QS. A I Isrā ': 82). Ministry of Religion of the Republic of Indonesia, the Koran and its translation, (Bandung: Publisher Jumānatul' AliArt, 2005). According to Pratika (2014) in Saputri (2015), "the effect of religious therapy listening to verses from the Qur'an on reducing violent behavior in RSJD. Dr. Amino Gondohutomo, Central Java Province "states that the results of research on violent behavior before receiving religious therapy are in the moderate category of 44 respondents $(56.4 \%)$, while for the low category of violence behavior, 47 respondents 
(60.3\%), after being treated with moderate violent behavior, 31 respondents ( 39.7 ) means that there is a decrease in violent behavior.

The purpose of this study was to apply the intervention of the application of murotal therapy to the risk of violent behavior klein

\section{METHOD}

The aim of this study is to describe the assessment process on the client's risky behavior without manipulation, and the author does not try to analyze Unexplained happened.

The number of subjects involved in this case study was 1 person. The subject criteria clients is Moslem with condition emotional passive assertive . The study's focus in this case study is the application of Murottal Surat Al-Fatihah to clients at risk of violent behavior using the Abraham-Hicks Emotional Scale Scoring method. The case study was conducted at RSIJ Bunga Rampai Klender Jakarta, April 2-6. This case study uses the Scoring observation sheet on the Emotional Scale According to Abraham-Hicks.

Data collection methods used at the time of the case study are directly and observation ting kat the increase or decrease in the Client Risk Behavior Therapy Violence after Murottal Surat Al-Fatihah.Good before or after done Tarapi Murottal Surat Al-Fatihah. Studi this case was done for five days in all subjects, prior to the intervention by the author of the first day to do relationship building mutual trust and author intent and purpose of the case study to the subjects, and then perform the initial assessment related to violent behavior after the author gives and asks consent to be a respondent in this case study after that carried out further studies, the second day began to intervene. Application of Al-Fatihah murottal therapy, before the subject therapy was carried out, a scoring measurement was carried out by assessing the client's emotions. and then recorded on the observation sheet then treatment three times a day and re-measured the client's emotional score by assessment

The presentation of this data uses a case study approach with a discrete method where this data assessment is carried out to determine the client's emotional decline after applying the Murot al Surat Al-Fatihah therapy using the Abraham-Hick Emotional Scale. 


\section{RESULTS}

This case study was conducted at the Mental Hospital, which is located on Jl. Bunga Rampai X No.6, RT.8 / RW.6, Malaka Jaya, Kec. Duren Sawit, East Jakarta City, Special Capital Region of Jakarta 13460. Bunga Rampai Klender, East Jakarta. The results of the case study and its discussion, which includes elaborating general data and specific data regarding the application of Al-Fatihah letter therapy to clients at risk of violent behavior on emotional scoring values.

In this case study, one person (client) is selected as the case study subject. the criteria have been set, as for the description of the subjects in this case study, namely: The subject is a 58-year-old woman, Muslim, last elementary school education, works as a housewife, the subject has a previous history of mental disorders. The subject's family says that the client is taken to the Klender Mental Hospital as he throws a tantrum threatens his husband, breaks things when studied Subject looks worried, face tense, eyes glare sound, and hands clenched into fists.

Assessment Results performed on the subjects involved in the case studies related to the implementation murottal therapy on risk of violent behavior clients with assessment scores ing can be seen as follows:

Subject:

The client said that he had previously been taken to a mental hospital because he often went berserk and broke things at home, the client hated his husband, his tone was high, unclear and funny, hands clenched, and the client did not feel sick and wanted to go home.

Based on data from the client's family, his work is angry at home. His high tone sometimes hits other people, especially her husband. Based on the data of above, the authors analyze the results of nursing diagnoses are clients with mental disorders related to the risk of violent behavior. Conduct an initial assessment (observation) related to assessing the emotional level of the subject neatly in the murottal of the Al-Fatihah letter to prevent prolonged emotional occurrence. This activity is carried out 3 times in 1 day

Nursing implementation in the application of Al-Fatihah's letter murottal therapy with the Abraham-Hicks emotional score can be seen in the table 1. 
Tabel 1. Application of Al-Fatihah's letter murottal therapy with the AbrahamHicks emotional score

\begin{tabular}{|c|c|c|c|c|c|}
\hline \multirow[t]{2}{*}{ Subject } & \multirow[t]{2}{*}{ Time } & \multirow{2}{*}{$\begin{array}{l}\text { Score } \\
\text { before } \\
\text { murottal } \\
\text { therapy }\end{array}$} & \multicolumn{2}{|c|}{ the result } & \multirow[t]{2}{*}{ Information } \\
\hline & & & score & $\begin{array}{l}\text { Emotional } \\
\text { level }\end{array}$ & \\
\hline & \multirow[t]{2}{*}{$2 / 4 / 19$} & (0) & \multirow[t]{2}{*}{0} & $(0)$ & \multirow{2}{*}{$\begin{array}{l}\text { The client said that she really } \\
\text { hated her husband, sometimes } \\
\text { cried, his tone was high, } \\
\text { unclear and funny }\end{array}$} \\
\hline & & Neutral & & Neutral & \\
\hline & \multirow[t]{2}{*}{$3 / 4 / 19$} & $(0)$ & \multirow[t]{2}{*}{0} & $(0)$ & \multirow{2}{*}{$\begin{array}{l}\text { the client looks restless, } \\
\text { awesome when spoken to, the } \\
\text { tone is high, the client does not } \\
\text { feel he is sick, }\end{array}$} \\
\hline & & Neutral & & Neutral & \\
\hline & \multirow[t]{2}{*}{$4 / 4 / 19$} & $(0)$ & \multirow[t]{2}{*}{0} & $(0)$ & \multirow{2}{*}{$\begin{array}{l}\text { The client looks restless, cool, } \\
\text { when the client examines it } \\
\text { says that he misses his } \\
\text { husband and children, the } \\
\text { client is sad, }\end{array}$} \\
\hline & & Neutral & & Neutral & \\
\hline & \multicolumn{2}{|l|}{$5 / 4 / 19$} & 1 & $(+1)$ Fine & $\begin{array}{l}\text { The client has begun to calm } \\
\text { down, the client feels healthy } \\
\text { and wants to go home } \\
\text { immediately, the client } \\
\text { forgives her husband's } \\
\text { mistakes, wants to be } \\
\text { appreciated by her husband, }\end{array}$ \\
\hline & \multicolumn{2}{|l|}{$6 / 4 / 19$} & 0 & $(+1)$ Fine & $\begin{array}{l}\text { The client feels } \\
\text { calm, confident, grateful, feels } \\
\text { healthy and wants to go home } \\
\text { soon, }\end{array}$ \\
\hline
\end{tabular}

From the table above shows the level of emotional decline in the 2 subjects before and after the Murott al Surat Al-Fatihah therapy which the author has summarized in the table below: 
Table 2. Results of the Abraham-Hick Emotional Scale

\begin{tabular}{|c|c|c|c|}
\hline subject & Score Before & Score After & Analysis \\
\hline Subject 1 & $(-1) \mathrm{Bad}$ & $\begin{array}{l}(+2) \\
\text { good }\end{array}$ & $\begin{array}{l}\text { The client said happy, happy, } \\
\text { confident, full of gratitude, } \\
\text { excited, missed his family, }\end{array}$ \\
\hline
\end{tabular}

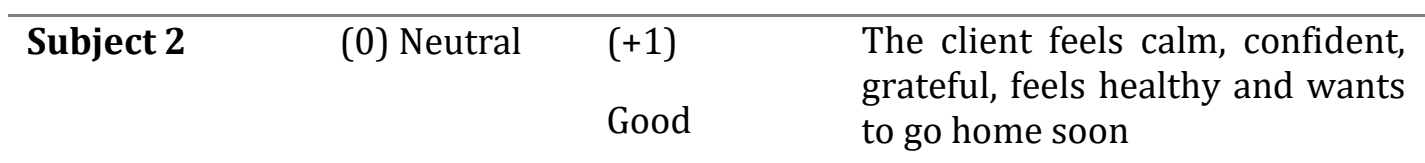

Based on the results of case studies carried out author of the two subjects, the results obtained before and after therapy Murottal Surat Al-Fatihah can be seen no decline. The client is calmer and more accepting of the circumstances of the test he is experiencing.

\section{Discussion}

The results of case studies have been described previously by the authors. Namely, authors determine in 2 subjects with the following criteria: subjects with violence behavior, assertive Muslim. The instrument used in this case study is the Abraham-Hick emotional scale. using observation sheets, and surat Al-Fatihah.

The steps set by the author are on the first day a relationship of mutual trust is carried out, explaining the intent and purpose of the case study to the subject, and asking for approval to become a respondent to intervene in the application of the Al- Fatihah letter therapy then the writer explains the meaning of the letter Al-Fatihah. The author asks the subjects to practice reading the letter Al-Fatihah. The evaluation of the application of Murottal Surat Al-Fatihah for 5 days showed that the two subjects' results decreased. It is caused by several factors that influence it, in this case, the writer sees changes in the emotional scale value based on the author's instructions to the subject directly and the author's motivation to the subject. This study's results can be concluded that the absorption of Murattal Surat Al-Fatihah therapy affects the subject. Based on the results of a case study conducted by Siswi Sri, entitled Effectiveness of Audio Therapy with Murotttal Surah Ar Rahman reduces violent 
behavior in RSJD. D r. Amino Gondohutomo, Central Java Province. The result is audio therapy listening to Surah Ar-Rahman. Effectiveness to reduce violent behavior. Likewise, research conducted by Pratika (2014) entitled "The Effect of Religious Therapy listening to verses of the Koran on reducing violent behavior in RSJD. Dr. Amino Gondohutomo, Central Java Province "states that the results of research on violent behavior before receiving religious therapy are in the moderate category of 44 respondents (56.4\%), while for low- categic violence behavior , 47 respondents $(60.3 \%)$, after being treated with moderate category violent behavior therapy, 31 respondents ( 39.7) means that there is a decrease in violent behavior. Research conducted by Pratika (2014)

\section{CONCLUSION}

Based on the results of the observations made about the effect of the Murottal Surat AlFatihah Therapy on clients at risk of violent behavior at the Klender Mental Hospital, East Jakarta, it is concluded as follows:

5.1 After conducting the case study, the writer found a decrease in the client's emotion or the risk of violent behavior by using Murottal Surat AlFatihah therapy for five days. The first subject before the Murottal Surat AlFatihah therapy was carried out on the first day of measurement and assessment, and on the fifth day, the client's emotional level decreased (+2) Very good.

5.2 The second subject before the Murottal Surat Al-Fatihah therapy was measured and the assessment was obtained a score of (0) Neutral followed by Murottal Surat Al-Fatihah therapy three times in one day the author did the scoring measurement there was no increase or decrease as well as on the second and three days there was no decrease namely (0) Neutral due to the client is not cooperative, and awkward when the author of the study. On the fourth day, the author did a reassessment of the score. The score was (0) Neutral, and after therapy, there was a decrease to (+1) Good. Likewise, on the same day Fifth, after the Murottal Surat AlFatihah therapy, the score did not increase or decrease, namely $(+1)$ Good. The client begins to calm down but still can't be cooperative when the assessment is carried out.

5.3 There was a significant decrease in Murottal Surat Al-Fatihah therapy for clients with emotional or risky behavior. 


\section{REFERENCES}

1. (uyun, 2014). Kesehatan jiwa menurut paradigma islam

2. sutejo. (2017). keperawatan jiwa. (w. s. atmenagara, Penyunt.) yogyakarta: pustaka baru press. doi:978-602-6237-38-5

3. keliat, b. a. (2009). manajemen kasus gangguann jiwa. jakarta: penerbit buku kedokteran.

4. keliat, b. a. (Penyunt.). (2006). model praktek keperawatan profesional jiwa. jakarta. doi:978-979-448-993-2

5. sutejo. (2017). keperawatan jiwa. (w. s. atmenagara, Penyunt.) yogyakarta: pustaka baru press. doi:978-602-6237-38-5

6. (Asih MinarningTyas, 2015). ). Buku Ajar Asuhan Keperawatan Klien dengan 5 Masalah Keperawatan Jiwa

7. Widhowati,S. 2010. "Efektifitas Terapi Audio dengan Murottal Surah ArRahman untuk Menurunkan Perilaku Kekerasan di RSJD Dr. Amino Gondohutomo Semarang" [Skripsi]. Semarang: Universitas Diponegoro.

8. Widi Afifah Nur Afifah (2017)

9. NANDA, (2009), Nursingdiagnoses : Definitions \& Classification 2009-2011. Philadelphia : NANDA International

10. Stuart, G.W (2009). Principle and Practice of Psyatric Nursing, 9th ed. Missouri : Mosby, Inc.

11. WHO. (2009). Improving Health System and Service for Mental Health : WHO Library Cataloguing-in-Publication Data.

12. Patricia G. O’Brien, Winifred Z. Kennedy, Karen A. Ballard (2014). Keperawatan Kesehatan Jiwa Psikiatrik. Penerbit Buku Kedokteran EGC 